\title{
A NEW DRAFT CODE FOR SEISMIC DESIGN OF BUILDINGS IN INDONESIA
}

\author{
I.A.N. Fraser*
}

\section{SYNOPSIS:}

The paper describes a new loading code for Indonesia developed under the aegis of the New Zealand Bilateral Aid Programme to Indonesia by the executing consultants, under the direction of a $\mathrm{NZ}$ Steering Committee and Indonesian Counterpart Team.

The paper summarizes the method of zoning, determining lateral load levels, and the assessment of factors relevant to the design loading code such as risk, ground condition, structural types, ductility and the development of the concept of dual documents namely:

(a) a code for use as the bylaw and for more complex structures, and

(b) a manual as a means of compliance with the code for easier design of straightforward buildings complying with one of a number of well defined structural types.

\section{INTRODUCTION AND BACKGROUND:}

In 1973 the Indonesian Government published in their Blue Book of desirable projects, an Earthquake Engineering Study, called project KTA6A, with the following principal objectives

: evaluation of existing seismic zoning maps and preparation of recommendations

: evaluation of existing seismic codes and related provisions, and preparation of recommendations

: training of Indonesian Engineers in Earthquake Engineering

Following keen interest by the $\mathrm{NZ}$ Ministry of Foreign Affairs and Beca Carter Hollings and Ferner Ltd, discussions and proposals in Indonesia led to the acceptance in late 1974 by the Indonesian Government, of Beca Carter Hollings and Ferner's credentials for undertaking the study and of an overall approach. Subsequently it was decided that the $\mathrm{NZ}$ input should be directed by a specially selected broad based committee including specialists in the range of disciplines necessary for zoning and drafting of regulations. By mid 1976 the committee was established together with the terms of reference for the executing consultants, Beca Carter Hollings and Ferner Ltd, and the project commenced under the aegis of the New Zealand Bilateral Assistance Programme to Indonesia. An Indonesian Counterpart Committee was also established to review the reports and recommendations of the New Zealand team and to assist with the obtaining of local data. Members of the Committees are acknowledged in the reports which present the findings of the study. ${ }^{2}{ }_{2}{ }_{3}{ }_{4}{ }_{5}{ }_{6} 7$

* Senior Director: Beca, Carter, Hollings \& Ferner Ltd, Consulting Engineers, Wellington, New Zealand.
The project was undertaken in 3 stages as listed below:

Stage I

(a) Review existing Indonesian seismic provisions and practices

(b) Collect data which is relevant to seismic activity and to zoning considerations

(c) Carry out any necessary processing of the data.

(d) Evaluate available data and information and make recommendations whether zoning is justified.

Stage II

If Stage I concludes zoning is justified undertake the necessary work to present zoning recommendations.

Stage III

(a) Recommend items to be covered by a code.

(b) Prepare a draft of the seismic provisions of a code for general structural design and design loadings.

The project also included training of two Indonesian Engineers at New Zealand University and in New Zealand design offices.

Following the completion of stage I, the project was extended to include the conducting of testing of full scale samples of Indonesian masonry construction under simulated inplane and face loading.

The following sections of this paper describe in summary form the conclusions of each stage and identify some of the policy decisions in drafting proposed new regulations. 


\section{REVIEW OF EXISTING CODE PROVISIONS:}

The existing loading code contained a formula for the calculation of the horizontal earthquake load on a building and its distribution. The formula included parameters for zone, soil type, structural material and importance factor. other seismic design considerations such as drift, separation and torsion were given in general terms.

The design procedure was essentially elastic and the concrete materials code included some seismic provisions similar to the ACI code provisions but excluding those relating to ductility.

It was recommended that consideration be given to reviewing load distribution, the use of different loads for structural type of different inherent ductility and more specific requirements for torsion, separation, drift and the distribution of forces according to member stiffnesses.

One frequent request from practising Engineers was that any recommended new code should be simpler and therefore reduce design time. It was difficult to give reassurance on this because of the general world trend toward more complex design codes, particularly for ductility provisions in materials codes. The need for ductile detailing was not generally well recognized and even existing code provisions often poorly understood.

A dominant feature of Indonesian construction was the use of masonry of locally made red bricks. Bricks are by far the most commonly used material for infill walls but are generally not load bearing except for single and two storey construction. The masonry is unreinforced except for "practical" columns and beams of similar thickness to the wall so that the usually plastered faces are planar. The design rule is empirical requiring panels of no greater area than 12 square metres between practical beams and columns.

The columns themselves generally contain 4 - $10 \mathrm{~mm}$ dia bars with $6 \mathrm{~mm}$ ties at about $300 \mathrm{~mm}$ spacing. This empirical approach was understood to have been established during the Dutch era. Such masonry walls were not considered in the analysis of structures (typically with a reinforced concrete frame) and walls were cast against "structural" members at random positions over the floor plan and elevation. The project was extended to include testing of full scale wall samples to assess the stiffness and strength of walls in relation to a typical frame. This was to confirm whether the stiffness of the walls in an unsymmetric wall configuration could lead to building torsions and unexpected ductility demands or "soft storeys", and also whether the walls could reliably be used as shear walls. ${ }^{7}$

Apart from the widespread use of the above noted masonry, in-situ reinforced concrete was found to be the most common structural material. The national reinforced concrete design code was based on elastic theory along the lines of
European practice.

Some structural steel construction was in evidence and in the absence of local material code, it was the custom to use recognized international codes.

Generally speaking, there was found to be a wide range in the quality of materials, in the standards of workmanship and in design; and this variability would be expected to be carried through to the ability of structures to resist earthquakes.

\section{SEISMOLOGICAL AND GEOLOGICAL DATA:}

The Indonesian Islands cover an enormous area extending some $45^{\circ}$ in longitude and $17^{\circ}$ in latitude. The Islands straddle the collision zones of the Indian-Australian, Pacific and Eurasian plates. The active margins contain trenches, young mountain ranges, volcanic arcs and frequent seismic activity. Other parts of Indonesia are in stable shelf areas with rare seismic activity.

Data on historical earthquake occurrence and late quaternary earth deformation in Indonesia were obtained from international agencies and from the relevant Indonesian Government departments and agencies.

\section{ZONING:}

It was concluded that there was enough data for a meaningful zoning to be carried out, but it was recommended that the zoning map is reviewed as more suitable geological research is undertaken and complete earthquake records are obtained over a longer period of time. The zoning method adopted is briefly described below but it has been described in more detail in a previous conference.

A seismic zone was defined as a region where the expected risk of structural and non-structural damage from earthquakes to normal buildings is approximately uniform.

This expected risk was calculated from an integration of

A. The expected frequency of occurrence of shallow earthquakes of different magnitudes at positions which would affect the site and

B. The patterns and strength of structural response expected from individual shallow earthquakes of different magnitude in Indonesia.

The following paragraphs summarise how assessments of these were obtained and subsequently integrated.

4.1 The expected occurrence of earthquakes in Indonesia.

(i) Indonesian earthquake listings were analysed to determine the historical frequency of occurrence of shallow earthquakes of varying magnitude. ${ }^{2}$

(ii) A review of Late Quaternary earth deformation was undertaken and a 
tectonic zoning map prepared. The map illustrated zones where earth deformation has occurred in the last $20,000,250,000$ and 2-3 million years. Work was carried out by G.J. Lensen of the D.S.I.R.

(iii).A study of the seismotectonic units of Indonesia was prepared and maximum typical earthquakes assigned to each unit. This was undertaken by Mr Eiby of the D.S.I.R.

(iv) A study of $b$ values ${ }^{I}$ in Indonesia was carried out and it was recommended that in symmetric units (Kalimantan, Stlawesi) b $\div 0.9$, and in asymmetric units (Java, Sumatra, Halmahera, West Irian, Minahassa Peninsula) $b \div 1.0$.

(v) The results of (i) to (iv) above were evaluated and a map illustrating the expected frequency of shallow earthquakes of magnitude 7.0 or more per square degree in Indonesia was prepared.

(vi) The earthquake occurrence map (from (v) above), the $b$ values and the maximum typical earthquakes in all regions allows the expected frequency of occurrence of earthquakes of any magnitude to be calculated throughout Indonesia.

Details of this procedure are given in references (2) and (3).

\subsection{Patterns of shaking in Indonesian Earthquakes.}

Because there are no strong-motion records of Indonesian earthquakes and only a few isoseismal maps, estimation of the patterns of shaking in Indonesian earthquakes was based on data from regions outside of Indonesia.

Elastic horizontal acceleration response spectra at 5\% damping were collected for a number of recorded strong-motions, and grouped in categories depending on regional location, magnitude, epicentral distance and site conditions; "Average" spectra were calculated for each category. Details of this procedure are given in references (3) and (9).

In constructing the attenuation curves emphasis was placed on Japanese strong-motion data, as, these were considered more representative of the likely shaking in Indonesian earthquakes than other sources.

It was found in constructing the attenuation curves that two site conditions are necessary (hard and soft ground) and that for each site condition only two curves are needed - one for short period structures and one for long period structures (with interpolation for other periods).

\subsection{Risk Calculations}

(i) The expected frequency of acceleration $\mathrm{I} b$ is the constant in the equation - Log $\mathrm{N}=\mathrm{a}-\mathrm{bM}$ where $\mathrm{a}$ is a constant and $\mathrm{N}$ is the frequency of occurrence of earthquakes in a specified region in the magnitude interval $M$ response at a site (for a given structural period and site condition) was determined by a straightforward integration procedure from the appropriate attenuation curves and the estimates of earthquake occurrence near the site.

(ii) Two refinements to the calculation procedure were necessary. The first was an adjustment to take account of the elliptical nature of the contours of equal shaking. The second refinement took account of the errors introduced by using deterministic attenuation relationships.

(iii) The risk was assessed at 30 sites throughout Indonesia, for each of the four combinations of soil type and natural period, and. contour maps constructed by allowing interpolation. The sensitivity of the maps to variations in the input data was assessed. Contour maps were drawn illustrating the peak acceleration response in elastic structures with 5\% damping expected on average every 20 years. Seismic zones were defined by specifying appropriate ranges in response level and are shown in Figure 1 which is an extract from the draft code.

\section{DESIGN LOADINGS CODE:}

The recommended draft design loadings code was developed from an examination of trends in other world codes and in particular the requirements of ATC3.10 The simplicity of the existing code and the general desire to maintain a simple and easily applied code led to less detailed analysis procedures than in other codes such as NZS 4203. The draft includes fairly standard references to matters such as torsion, inter-connection, method of analysis, symmetry, dynamic analysis etc. and includes a formula for calculating the horizontal seismic load of:

$$
V=C I K W_{t}
$$

Where $V$ is the total horizontal seismic base shear and $W_{t}$ is the weight of the structure (including some live load).

$C$ is the basic seismic coefficient which depends on the risk of potentially damaging ground motions at the site, the natural period of vibration of the structure and the stiffness of the foundation soils.

I is the importance factor, which takes a value of 1.0 for typical structures. Higher values are used for important structures to provide a decrease in the probability of damage.

$\mathrm{K}$, the structural type factor, is intended to reflect the potential performance of different types of structures and materials in severe earthquakes. Structures with substantial ductility and capable of dissipating 


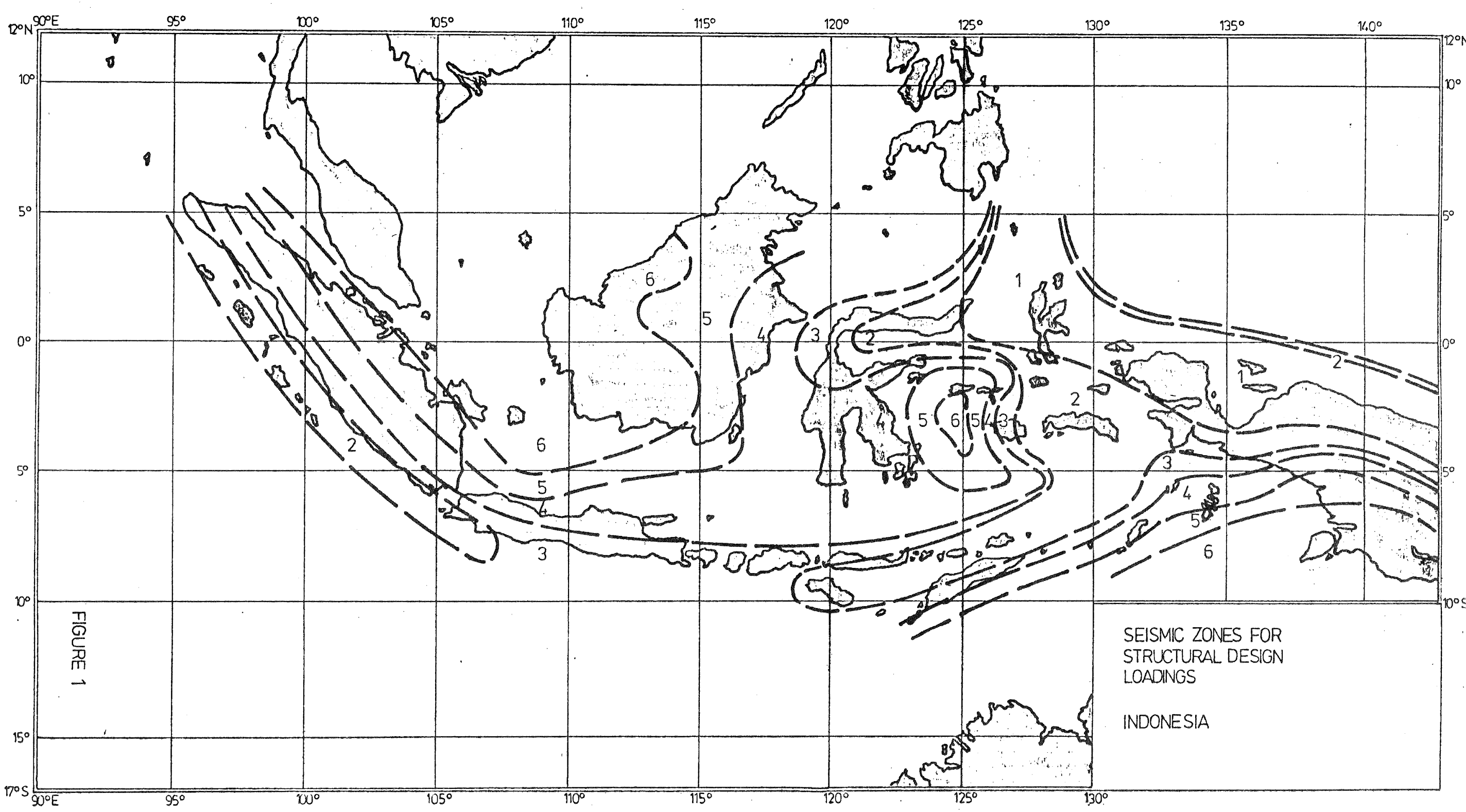


energy at a substantial number of locations (where plastic hinges form) are assigned low $K$ values and $K$ increases as the available ductility decreases.

Values for $C$, I and $\mathrm{K}$ were developed in accordance with the following philosophy:

1. The lateral strength of the building should be sufficient to ensure that the expected frequency of occurrence of onset of structural damage is acceptable.

2. The lateral strength of the building should be sufficient to ensure the probability of ground shaking in a severe earthquake causing deflections and strains beyond the capacity of the structure is acceptable in the assumed life of the structure.

The values of $C$ and $I$ were set by criterion 1 and $K$ by criterion 2 .

\subsection{Determination of Basic Coefficient C:}

Assuming $K=1$ and $I=1$, values of $C$ were set from the risk analysis carried out in stage II of the project such that for any combination of site condition (soft or firm), natural period of vibration of the structure, and seismic zone, the expected average return period of an earthquake response causing the possible onset of structural damage was approximately equal and acceptable. The structural response causing the possible onset of damage was defined as that required for the structure to reach full over-strength stresses in a significant number of elements. Using the load levels in the previous code the "acceptable" return period for stiff structures on soft ground in the Jakarta zone was calculated to be approximately 20 years. (It should be noted that this calculation is probably conservative because the numerous assumptions in its derivation are likely to be slightly conservative. Therefore one would expect a real structure in Jakarta to respond to the level of incipient damage less frequently than a long term average of 20 years.) Once this 20 year average return period was set, the values of $\mathrm{C}$ for other zones, soil types and structural periods followed from work carried out in Stage II. These are shown in figure 2 which is an extract from the draft code.

\subsection{Determination of Importance Factor}

The desired level of earthquake protection varies depending on the importance of the facility and the consequences of failure. An importance factor, I was used to change the lateral design load to achieve the required degree of acceptable risks of the potential onset of damage. For normal structures I is 1.0 .

To illustrate, an increase in response from 0.05 to 0.075 for zone 4 corresponds to an increase in return period from 20 to 30 years for stiff structures on soft ground. Similar calculations for other return periods, soil conditions and seismic zones lead to generalised values for $I$.
Change in return period

Importance Factor (

$\begin{array}{ll}.67 & \text { times } \\ 1.5 & \text { times } \\ 2 & \text { times } \\ 5 & \text { times }\end{array}$

0.8

1.5

1.7

2.0

Strictly, for a given change, I depends on the seismicity, the natural period and on site conditions, but the variation was not worth considering and an average value was adopted.

\subsection{Determination of the Structural Type Factor (K)}

The purpose of the structural type factor in the loading expression was to take account of the expected difference in post elastic performance of varying structure types and materials in severe earthquakes. The $\mathrm{K}$ factor provides sufficient lateral strength to ensure that demands do not exceed available ductility in severe earthquakes. Structures with substantial ductility and which are capable of dissipating energy in a significant number of members were given low $\mathrm{K}$ factors. Structures which have few energy dissipating mechanisms need to have higher lateral strength to provide adequate protection in severe shaking. These structures have higher $\mathrm{K}$ factors.

$K$ was assessed on both the configuration of the structure and the material of construction.

Values of $\mathrm{K}$ were calculated for the major structural types from an assessment of available ductility and a "design" severe earthquake defined in terms of elastic response. Using the existing code loads, $K=1$, and an assessment of available ductility in concrete frame structures being constructed in Jakarta, it was assessed that the "design" earthquake had an expected average return period of at least 200 years. Again, this calculation is conservative because of the number of probably conservative assumptions contained in its derivation and the real equivalent elastic response is likely to have a significantly greater return period. This level of risk (similar to existing ductile reinforced concrete framed structures in Jakarta) was deemed acceptable by the Indonesian Committee and adopted for the calculation of $\mathrm{K}$ values for other structural and material types. The recommendations and contents of ATC 3 were used extensively in the assessment of available ductility in structural types for which $\mathrm{K}$ values were given in the code. $K$ values range from 1.0 for structures with relatively high ductility to 4.0 for structures with little.

Ductility provisions were found to be inadequate in the existing concrete code and additional requirements were included in an appendix to the design Manual.

\section{DESIGN MANUAL:}

Although the design code was kept as simple as possible it was appreciated by the project team that some resistance 

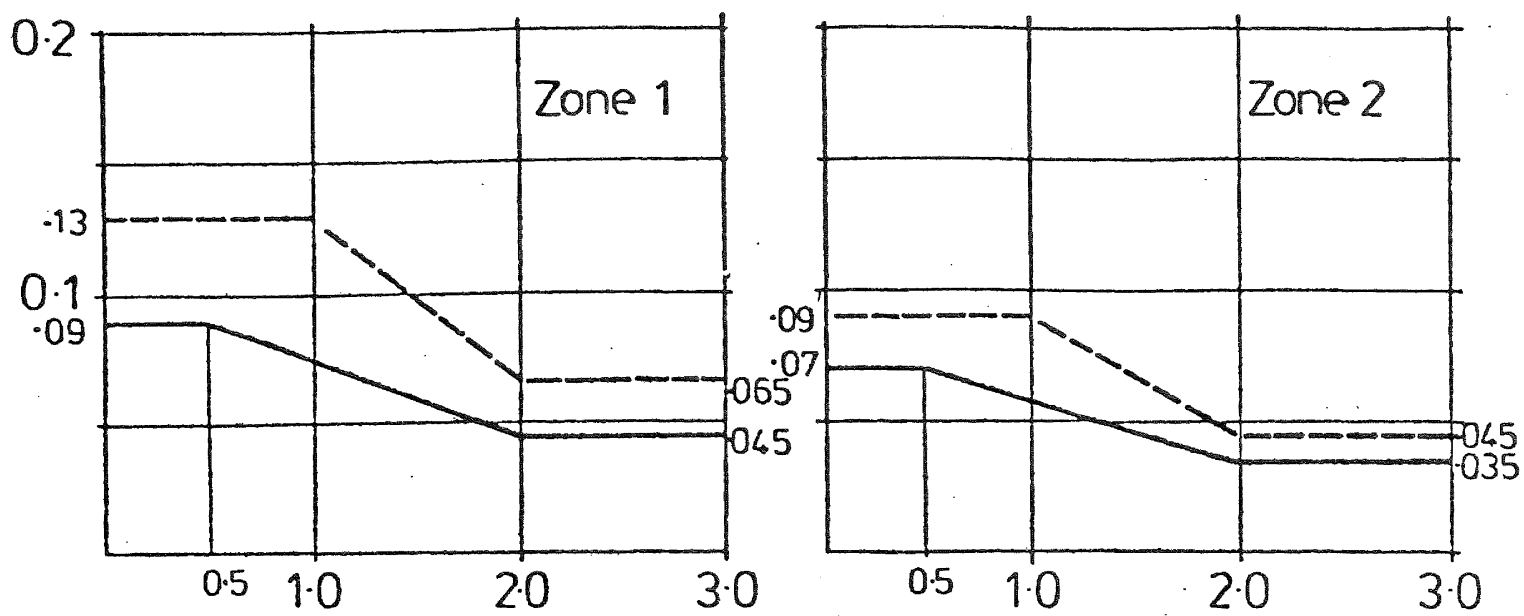

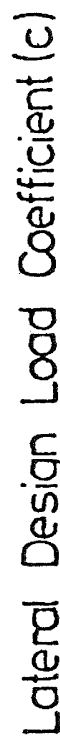
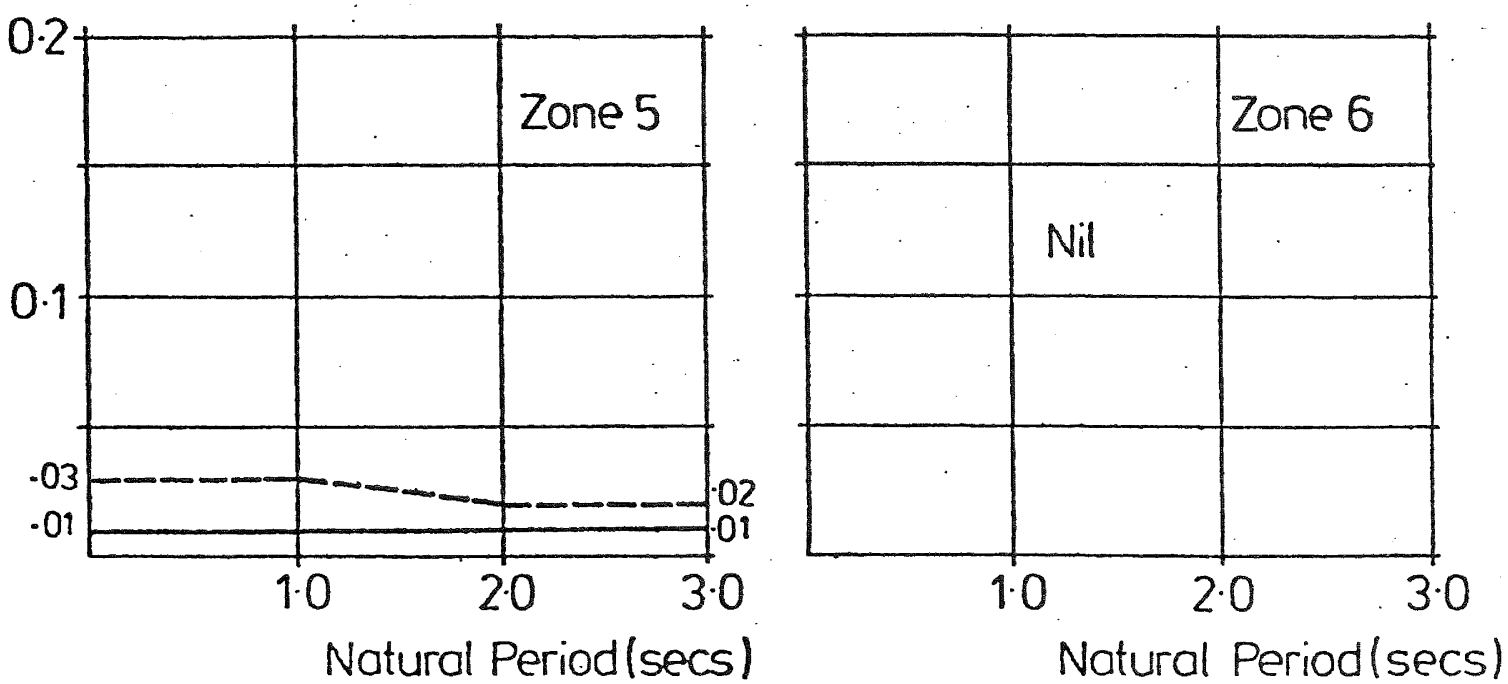
might arise from the building industry because of increased design effort. However, if structures were to be adequately designed there could be no further simplification or standards would be compromised or generally applicable rules be made so sweeping that some instances would be too conservative.

The concept of a manual was developed as a means of compliance with the draft code (which could become a bylaw). The Manual was a simplified or "cookbook" approach which would require neither the level of expertise nor the design time that was required by the full code. The manual could be applied to only relatively small simple structures with a high degree of regularity. More complex or larger structures would be designed in full in accordance with the code.

The manual approach was considered practical for the Indonesian industry because of the limited range of building materials and structural systems under frequent use.

Seven standard structural types were chosen as representative and these are described in table 1 which is extracted from the draft manual.

Type A was a new suggestion based on the masonry testing programme which demonstrated that the masonry construction could be used as shear walls providing the reinforcing is increased and providing a ductile frame also exists to give greater over all ductility.

Type B was a typical reinforced concrete frame with infill brick walls, Bl allowing random walls but low height and B2 allowing greater height but a symmetrical wall layout.

Type D is similar to B but with separation required at infill walls because of an increase in allowable height and random wall layout.

Type $\mathrm{C}$ is a reinforced concrete masonry shear wall building to allow for the increasing (though still modest) manufacture of concrete masonry.

For each structural type a specific formula and analysis method is stated with unnecessary calculations omitted. For example: torsion calculation is not required for structures meeting strict rules for symmetry and the " $K$ " factors are built in to the " $\mathrm{C}$ " factors; design charts are given for reading off values of parameters in formulae for bending moment calculations.

\section{CONCLUSION:}

It is believed that a useful set of documents have been developed during the project with a high level of acceptability to the Indonesian Engineering profession. The participation of the Indonesian counterpart team in the developmental discussions in both Indonesia and in New Zealand caused the necessary local input to be available at the correct stages. All data and drafts were circulated freely between the two committees in both countries either directly or more usually through the executing consultants. Although this took a little longer than hoped it led to a greater base for decision making and a greater sense of involvement for 211 parties.

\section{ACKNOWLEDGEMENTS:}

Acknowledgement must be given to the NZ Ministry of Foreign Affairs; the NZ Steering Committee, including Messrs McKenzie, Butcher, Eiby, Lensen, Drs Skinner and Smith and particularly the late Mr O.A. Glogau who was the chairman; the Indonesian Counterpart Team and the Beca Cartex Hollings and Ferner team of Messrs Bentley, Binney and Hollings.

\section{REFERENCES :}

1. Beca Carter Hollings and Ferner Ltd et al. A Review of Existing Indonesian Seismic Provisions and Practices. Unpublished Volume 1 of Indonesian Earthquake Study, 1977.

2. Beca Carter Hollings and Ferner Ltd et al. Earthquake Risk in Indonesia: Collation of Seismological and Geological Data. Unpublished Volume 2 of Indonesian Earthquake Study, 1980.

3. Beca Carter Hollings and Ferner Ltd et al. Seismic zones for Building Construction in Indonesia. Unpublished Volume 3 of Indonesian Earthquake Study, 1980 .

4. Beca Carter Hollings and Ferner Ltd et al. Lateral Loadings for Earthquake Resistant Design of Building Construction in Indonesia. Unpublished Volume 4 of Indonesian Earthquake Study, 1981.

5. Beca Carter Hollings and Ferner Ltd et al. Draft Code of Practice for Seismic Design of Building Construction in Indonesia. Unpublished Volume 5 of Indonesian Earthquake Study, 1981.

6. Beca Carter Hollings and Ferner Ltd et al. Manual for the Design of Normal Reinforced Concrete and Reinforced Masonry Structures in Indonesia. Unpublished Volume 6 of Indonesian Earthquake Study, 1981.

7. Beca Carter Hollings and Ferner Ltd et al. Masonry Testing. Unpublished Volume 7 of Indonesian Earthquake Study, 1981.

8. Bentley R.J., and Zen M.T. The Seismic Zoning of Indonesia for Normal Building Construction. 2nd South Pacific Conference on Earthquake Engineering, Wellington, 1979. 
9. Bentley R.J., Average Estimates of the Attenuation of 5\% Damped Horizontal Acceleration Response, Proc. 2nd South Pacific Conference on Earthquake Engineering, Wellington 1979 .

10. United States Applied Technology

Council "Tentative Provisions for the Comprehensive Seismic Design of Buildings", 1978.

TABLE 1 : DESIGN MANUAL - STRUCTURAL TYPES

\begin{tabular}{|c|c|c|c|c|c|c|}
\hline $\begin{array}{l}\text { Res } \\
\text { The }\end{array}$ & $\begin{array}{l}\text { ictions on } \\
\text { tructural Form }\end{array}$ & $\mathrm{A}$ & $\mathrm{Bl}$ & B2 & C & $\mathrm{D}$ \\
\hline I. & $\begin{array}{l}\text { Construction } \\
\text { Material }\end{array}$ & $\begin{array}{l}\text { Reinforced Concr. } \\
\text { Frame }\end{array}$ & $\begin{array}{l}\text { Reinforced } \\
\text { Concr.Frame }\end{array}$ & $\begin{array}{l}\text { Reinforced } \\
\text { Concr.Frame }\end{array}$ & $\begin{array}{l}\text { Reinforced } \\
\text { Concr. } \\
\text { Masonry }\end{array}$ & $\begin{array}{l}\text { Reinforced. } \\
\text { Concr. Frame }\end{array}$ \\
\hline 2. & Maximum Height: & $\begin{array}{l}4 \text { Storeys or } \\
14 \text { metres }\end{array}$ & $\begin{array}{l}2 \text { storeys } \\
\text { or } 8 \text { metres }\end{array}$ & $\begin{array}{l}7 \text { storeys } \\
\text { or } 25 \text { metres }\end{array}$ & $\begin{array}{l}3 \text { Storeys } \\
\text { or } 11 \text { metres }\end{array}$ & $\begin{array}{l}10 \text { Storeys } \\
\text { or } 35 \text { metres }\end{array}$ \\
\hline 3. & $\begin{array}{l}\text { Separation of } \\
\text { Masonry Infill } \\
\text { walls from the } \\
\text { structure: }\end{array}$ & $\begin{array}{l}\text { Not } \\
\text { separated }\end{array}$ & $\begin{array}{l}\text { Not } \\
\text { separated }\end{array}$ & $\begin{array}{l}\text { Not } \\
\text { separated }\end{array}$ & $\begin{array}{l}\text { Not } \\
\text { separated }\end{array}$ & Separated \\
\hline 4 & $\begin{array}{l}\text { Limitations on } \\
\text { Masonry Infill } \\
\text { Walls: }\end{array}$ & $\begin{array}{l}\text { Reasonably } \\
\text { symmetrical } \\
\text { placement. The } \\
\text { sum of the } \\
\text { lateral load } \\
\text { resisting wall } \\
\text { thickness must } \\
\text { exceed } \\
35 \Sigma^{\mathrm{I}} \mathrm{j} \\
\text { for red brick } \\
\text { or } \\
120 \Sigma_{\frac{\mathrm{T}}{\mathrm{H}}}^{\mathrm{H}} \\
\text { for batako. }\end{array}$ & $\begin{array}{l}\text { Random } \\
\text { wall } \\
\text { placement. }\end{array}$ & $\begin{array}{l}\text { Reasonably } \\
\text { symmetrical } \\
\text { placement. }\end{array}$ & $\begin{array}{l}\text { Random } \\
\text { wall } \\
\text { placement. }\end{array}$ & $\begin{array}{l}\text { Random Wall } \\
\text { placement. } \\
\text { No limit on } \\
\text { wall place- } \\
\text { ment. }\end{array}$ \\
\hline 5. & $\begin{array}{l}\text { Assumed Struct- } \\
\text { ural Performance } \\
\text { of Infill Walls: }\end{array}$ & $\begin{array}{l}\text { Infill walls } \\
\text { assist seismic } \\
\text { load resistance. }\end{array}$ & $\begin{array}{l}\text { Effect of } \\
\text { infill walls } \\
\text { ignored }\end{array}$ & $\begin{array}{l}\text { Effect of } \\
\text { infill walls } \\
\text { ignored }\end{array}$ & $\begin{array}{l}\text { Effect of } \\
\text { infill walls } \\
\text { ignored }\end{array}$ & $\begin{array}{l}\text { Effect of } \\
\text { infill walls } \\
\text { ignored }\end{array}$ \\
\hline
\end{tabular}

